\title{
Prophylaxis and management of postoperative nausea and vomiting in enhanced recovery protocols: Expert Opinion statement from the American Society for Enhanced Recovery (ASER)
}

\author{
Ruchir Gupta ${ }^{1 *}$ and Roy Soto ${ }^{2}$
}

\begin{abstract}
International experience and evidence-based practices have shown that reduction in variability through use of protocolized perioperative care improves surgical outcomes and reduces costs to patients and healthcare systems. In this series of Expert Opinions, we provide consensus recommendations for the various components of perioperative care to aid with the development of enhanced recovery after surgery protocols.
\end{abstract}

Keywords: Nausea, Vomiting, Prophylaxis, Expert Opinion

\section{Main text}

\section{Parameter definition}

Early ambulation, early feeding, and early return of bowel function are linked with quicker recovery, earlier discharge, and improved satisfaction. Postoperative nausea and vomiting (PONV) is a common complication following abdominal surgical procedures with patient (young age, female sex, history of motion sickness), anesthetic (use of opioids and volatile anesthetics), and surgical (length of case, use of insufflation, manipulation of the bowel) factors contributing to its incidence and severity. Nausea and vomiting should be viewed as existing on a continuum, and sequelae and patient discomfort vary based on patient experience, surgical procedure, and recovery profile. Guidelines for its avoidance and treatment are based on evidence-based literature, expert opinion, and professional association recommendations [ASPAN'S evidence-based clinical practice opinion for the prevention and/or management of PONV/PDNV. J Perianesth Nurs 2006 [Gan et al. 2007] Gan et al. 2014. Gan et al. 2003.

\footnotetext{
* Correspondence: guptar2005@yahoo.com

${ }^{1}$ Stony Brook University School of Medicine, Stony Brook, NY, USA Full list of author information is available at the end of the article
}

\section{Discussion}

Prophylaxis of PONV is based on a number of risk factors [Apfel et al. 1999, presented here as modifiable and non-modifiable:

1. Modifiable risk factors
a. Use of volatile anesthetics
b. Intraoperative use of opioids
c. Surgical/anesthetic time
d. Smoking (tobacco use decreases PONV risk)

2. Non-modifiable risk factors Apfel et al. 2012a
a. Female sex
b. Young age $(<50)$
c. History of PONV
d. Surgical location (abdominal/pelvic, ENT, breast)
e. Surgical technique (laparoscopic)

The number of medications/techniques used for prophylaxis is dictated by the numbers of risk factors present. Patients with $\leq 1$ risk should be considered at low risk, and those with $\geq 3$ should be considered at high risk [Apfel et al. 2012b]. Prophylaxis and treatment should rely on modification of anesthetic technique, if possible, and the use of medications that work at a variety of receptor sites allowing for full multimodal benefit. 
Non-pharmacologic techniques include ensuring appropriate analgesia and hydration, acupuncture/acupressure, and aromatherapy. Pharmacologic techniques include medications that work at different receptor sites:

1. Serotonin antagonists (e.g., ondansetron)

2. Dopamine antagonists (e.g., droperidol, metoclopramide)

3. Anticholinergics (e.g., scopolamine)

4. Antihistamines (e.g., diphenhydramine)

5. Steroids (e.g., dexamethasone)

6. Others (e.g., trimethobenzamide)

\section{Conclusion}

\section{ASER Expert Opinion}

All patients should receive PONV prophylaxis during the perioperative period. The numbers of medications used for treatment and prophylaxis should be determined by the number of modifiable and non-modifiable risk factors. Medications used should represent different mechanisms of action in an attempt to achieve multimodal benefit Tramèr 2001.

\section{Abbreviations}

ASER: American Society for Enhanced Recovery; ENT: ear, nose, and throat; PONV: postoperative nausea and vomiting.

\section{Competing interests}

The authors declare that they have no competing interests.

\section{Authors' contributions}

Dr. RG wrote the initial draft of the Expert Opinion. Dr. RS performed further research and edited the final draft. Both authors performed literature searches as it relates to the topic of postoperative nausea and vomiting. Both authors read and approved the final manuscript.

\section{Authors' information}

Ruchir Gupta is a member of the organizational committee of the American Society for Enhanced Recovery, and Roy Soto is a member of the board of directors for the American Society for Enhanced Recovery. Both are also founding members of this organization.

\section{Acknowledgements}

The authors wish to make no acknowledgements at this time.

\section{Author details}

${ }^{1}$ Stony Brook University School of Medicine, Stony Brook, NY, USA. ${ }^{2}$ Oakland University William Beaumont School of Medicine, Royal Oak, MI, USA.

Received: 16 January 2016 Accepted: 10 February 2016

Published online: 02 March 2016

\section{References}

Apfel CC, Läärä E, Koivuranta M, Greim CA, Roewer N. A simplified risk score for predicting postoperative nausea and vomiting: conclusions from crossvalidations between two centers. Anesthesiology. 1999;91:693-700.

Gan TJ et al. Consensus opinions for the management of postoperative nausea and vomiting. Anesthesia and Analgesia. 2014;118:85-113.

Apfel CC, Philip BK, Cakmakkaya OS, Shilling A, Shi YY, Leslie JB, et al. Who is at risk for postdischarge nausea and vomiting after ambulatory surgery? Anesthesiology. 2012a;117:475-86.

Apfel CC, Heidrich FM, Jukar-Rao S, Jalota L, Hornuss C, Whelan RP, et al. Evidence-based analysis of risk factors for postoperative nausea and vomiting. Br J Anaesth. 2012b;109:742-53.
Tramèr MR. A rational approach to the control of postoperative nausea and vomiting: evidence from systematic reviews. Part I. Efficacy and harm of antiemetic interventions, and methodological issues. Acta Anaesthesiol Scand. 2001:45:4-13.

Gan TJ, Meyer T, Apfel CC, Chung F, Davis PJ, Eubanks S, et al. Consensus guidelines for managing postoperative nausea and vomiting. Anesth Analg. 2003;97:62-712.

Gan TJ, Meyer TA, Apfel CC, Chung F, Davis PJ, Habib AS, et al. Society for Ambulatory Anesthesia guidelines for the management of postoperative nausea and vomiting. Anesth Analg. 2007;105:1615-283.

ASPAN'S evidence-based clinical practice opinion for the prevention and/or management of PONV/PDNV. J Perianesth Nurs 2006;21:230-50
Submit your next manuscript to BioMed Central and we will help you at every step:

- We accept pre-submission inquiries

- Our selector tool helps you to find the most relevant journal

- We provide round the clock customer support

- Convenient online submission

- Thorough peer review

- Inclusion in PubMed and all major indexing services

- Maximum visibility for your research

Submit your manuscript at www.biomedcentral.com/submit 